MAN AND SOCIETY IN NINETEENTH-CENTURY REALISM 
By the same author

Gathering Pace: Continental Europe, I 870-I945

Church and State after the Dreyfus Affair 


\title{
MAN AND SOCIETY IN NINETEENTH-GENTURY REALISM
}

Determinism and Literature

\author{
MAURICE LARKIN
}

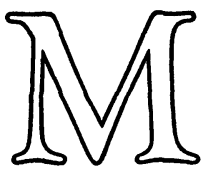


(C) Maurice Larkin 1977

Softcover reprint of the hardcover 1st edition 1977

All rights reserved. No part of this publication may be reproduced or transmitted, in any form or by any means, without permission

First published 1977 by THE MACMILLAN PRESS LTD

London and Basingstoke Associated companies in Delhi Dublin Hong Kong Johannesburg Lagos Melbourne New Tork Singapore Tokyo

ISBN 978-1-349-01663-1 ISBN 978-1-349-01661-7 (eBook) DOI 10.1007/978-1-349-01661-7

This book is sold subject to the standard conditions of the Net Book Agreement 


\section{Contents}

Foreword and Acknowledgements vii

I Beating the Bounds I

PART ONE STENDHAL, BALZAC AND DETERMINISM

The social and intellectual context 7

2 The Shaping Forces of Society: Stendhal's Europe 9

3 Determinist Thought: Stendhal and the

Eighteenth-century Inheritance $\quad$ I7

4 Man and Beast: the Balzacian Jungle $3^{1}$

5 Une Société Embourgeoisée? Balzac's France 42

PART TWO FACING REALITY: DETERMINISM

AND THE REALIST RESPONSE Büchner, Flaubert,

Mrs Gaskell, George Eliot, Turgenev, Tolstoy 53

6 Pessimism $\quad 55$

7 More Pessimism: Flaubert $\quad 66$

8 The Industrial Revolution 74

9 A Modus Vivendi? George Eliot $\quad 89$

Io Russia and the Realist Response: Turgenev 98

I I Experience versus the Intellect: Tolstoy ${ }^{2}$ I I

PART THREE LATER RESPONSES Zola, Ibsen,

Fontane, Chekhov 121

12 La Bête Humaine 123

I3 The Ubiquitous Doctor 134

I4 The Dismal Science: Economic Man 139

I5 Society versus the Individual $\quad$ I52

I6 Hope and Despair $\quad$ I63

Appendix A The Determinist Case $\quad 175$

Appendix B Tristram Shandy, Determinism and Prediction $\quad$ I 78

$\begin{array}{ll}\text { Appendix C Eliot's Moral Dialectic } & \text { I } 79\end{array}$

$\begin{array}{ll}\text { Appendix D Zola, Heredity and Environment: } & \\ \text { Gervaise and her sons } & 182\end{array}$

Appendix E Zola and the Manual Classes $\quad$ I84

Appendix F Ibsen, the Individual and Environment:
Ghosts and A Doll's House

$\begin{array}{ll}\text { Some books } & \mathrm{I} 88\end{array}$

$\begin{array}{ll}\text { Index } & 195\end{array}$ 


\section{Foreword \\ and Acknowledgements}

For twenty-five years he has been chewing over other people's ideas about realism, naturalism and all that sort of nonsense; for twenty-five years he has been lecturing and writing about things that intelligent people have known all the time...

\section{Uncle Vanya}

Disraeli once remarked that if he wanted to read a book, he wrote one. While for Disraeli this was perhaps a guarantee that the book would be worth reading, necessity rather than conviction first prompted this particular venture. As the non-academic knows from daily experience, life is an interdisciplinary business. Yet when universities and colleges paid tribute to the fact by launching a variety of interdisciplinary programmes, it immediately became apparent that there was a serious shortage of suitable books. As in the days before the printing-press, the lecturer reverted to being the fountainhead of knowledge and wisdom; the spoken word and the cyclostyled sheet acquired an oracular importance. And although academics were initially flattered by the unaccustomed spectacle of capacity audiences in their hard-benched lecture theatres, the education columnists of the quality press were quick to assert a state of 'frustration and disenchantment' among staff and students alike, especially in the newer universities.

The paucity of suitable books still remains a problem, despite the achievements of the last ten years. And the problem becomes especially difficult when the subject covers several countries as well as disciplines. The main currents of nineteenth-century literature and thought continue to be unevenly served, despite the breadth of their appeal among the general reading public, and despite their entrenched position in degree syllabuses. It is especially surprising that such a well-trodden field as Realist literature should have so few introductory surveys that treat it both internationally and as the product of social and intellectual change. There is no shortage of outline accounts of Realism, although most of these confine themselves to the literature of one language. Nor is there a dearth of social and intellectual histories of the nineteenth century. But few histories are written with an eye to the requirements of the literature reader; and of those that are, the majority are restricted to the writers of a particular country. 
Man and Society in Nineteenth-century Realism is unlikely to bring enchantment to the disenchanted, nor can it aspire to allay the suspicions of sceptics-particularly those who have misgivings about interdisciplinary activities. It is intended for the reader who requires an introduction to the determinist issues latent in Realism, and who wants an outline of the circumstances that engendered them. It examines the growing attention that thinkers of the eighteenth and early nineteenth centuries paid to environment and heredity as shaping forces; and it indicates how the social consequences of the French and Industrial Revolutions made writers aware that they were living in a rapidly shifting society that was moulding men in new and often disconcerting ways. The book compares the responses of the better known Realists to these developments: notably Stendhal, Balzac, Büchner, Mrs Gaskell, Flaubert, George Eliot, Turgenev, Tolstoy, Zola, Ibsen, Fontane and Chekhov. It considers their prescriptions for coming to terms with determinism; and it examines in particular the efforts of those who tried to find a foothold for morality and hope in a world where free will and autonomous choices no longer had an assured place, except on the level of subjectivity. Close attention is paid to the more ingenious of those endeavours, notably George Eliot's attempt to resolve the problem by taking a dichotomous view of life, distinguishing 'subjective' from 'objective' reality.

The final chapters look at the Realists' response to the economic changes of the later nineteenth century. They similarly outline the Realists' various reactions to evolutionary concepts of Man. From Balzac to Chekhov, la bête humaine had been a prime concern of Realism; and one of the continuing themes of the book is the literary legacy of evolutionary ideas, particularly those of Lamarck, Geoffroy Saint-Hilaire and Darwin.

Most introductions to Realism are concerned with it as a species of creative art, rather than as a response to changing concepts of Man and society. In reversing this emphasis, this book attempts to meet a need among readers for a survey where the focus is as much historical as literary.

The inherent shortcomings of such an undertaking are evident enough. The decision to restrict illustration to a handful of works that are familiar and easily accessible in cheap translation (the editions used are listed at the end of this Foreword) has resulted in some sad omissions. Italian Verismo is nowhere represented; and in the case of other literatures, a number of the points at issue could have been more cogently demonstrated by other works and authors, less readily available in English. It may seem odd, for instance, that figures such as Champleury and Duranty make no appearance. But given the brevity of the book, it seemed advisable to confine it to the authors and works that are the staple fare of the general reader, and which feature widely in the multitude of degree-courses on nineteenth-century literature. 
This undertaking owes a great deal to the University of Kent-particularly to the staff and students who participated in the interdisciplinary course on nineteenth-century Realism. Their knowledge and thoughts - and, above all, their scepticism-were a salutary sedative in times of unbuttoned enthusiasm; and if their subsequent warnings have been insufficiently heeded in these pages, it was not for want of trying on their part. On more specific issues, Mr. Edward Greenwood, Professor Maurice Crosland, Mr. John Gooding and Dr. Nicholas Phillipson have been a benevolent source of helpful comment and information. The book has also been very dependent on the patience, as well as the advice, of others. Mr T. M. Farmiloe of Messrs Macmillan has been generous with both, while Mrs Muriel Waring, Miss Beverley Spear and their colleagues completed the typing with remarkable cheerfulness, despite the tightest of schedules. As always, however, it is the writer's unhappy family which bears the burden of any book, and few families have endured so much as in this case. Even at his most dispiriting, the Reverend Edward Casaubon of Middlemarch never strained his wife's forebearance to quite the same degree; and if Man and Society in Nineteenth-century Realism has much in common with his Key to all mythologies, its open incitement to a Will Ladislaw to appear and complicate the marital scene is not the least of them.

September 1976

MAURIGe Larkin

\section{Editions used}

The editions mainly cited are Stendhal, Scarlet and Black, tr. Margaret R. B. Shaw (Penguin, I 953); Balzac, Cousin Bette, tr. Marion A. Crawford (Penguin, I965); Balzac, A Harlot High and Low (Splendeurs et misères des courtisanes), tr. Rayner Heppenstall (Penguin, 1970); Büchner, Complete Plays and Prose, tr. Carl R. Mueller (Hill and Wang, I963); Mrs. Gaskell, Mary Barton (Everyman, I965); Mrs. Gaskell, North and South (Penguin, 1970); Flaubert, Sentimental Education, tr. Anthony Goldsmith (Everyman, 1962); George Eliot, Middlemarch (Penguin, I965); George Eliot, Felix Holt, the Radical (Panther, I965); Turgenev, Fathers and Sons, tr. Barbara Makanowitzky (Bantam, I959); Tolstoy, Anna Karenin, tr. Rosemary Edmonds (Penguin, I954); Zola, L'Assommoir, tr. Atwood H. Townsend (Signet, I962); Zola, Germinal, tr. L. W. Tancock (Penguin, I954); Zola, Earth, tr. Ann Lindsay (Arrow, I967); Four Great Plays by Henrik Ibsen. A Doll's House. Ghosts. An Enemy of the People. The Wild Duck, tr. R. Farquharson Sharp (Bantam, 1967); Fontane, Effi Briest, tr. Douglas Parmée (Penguin, 1967); Plays by Anton Chehov, tr. Elisaveta Fen (Penguin, 1964). 